\title{
Metode Forward Chaining Untuk Penentuan Kelayakan Bisnis Usaha Mikro
}

\author{
Dedy Kurniadia,", Toni Prahasto ${ }^{\mathrm{b}}$, Ibnu Widiyanto ${ }^{\mathrm{c}}$ \\ a Jurusan Teknik Informatika Universitas Islam Sultan Agung \\ ${ }^{\mathrm{b}}$ Teknik Mesin Fakultas Teknik Universitas Diponegoro \\ ${ }^{c}$ Manajemen Fakultas Ekonomika dan Bisnis Universitas Diponegoro
}

Naskah Diterima : 3 Maret 2016; Diterima Publikasi : 27 Mei 2016

DOI: $10.21456 /$ vol6iss1pp66-75

\begin{abstract}
In this present study has done business feasibility of the micro industrial sector. This study is based on the importance of Business Feasibility Study (BFS) on the business organization that requires an assessment of the feasibility of the business process as a benchmark also to minimize the business risks that may occur to be dealt with appropriately. This research aims to create a Business Feasibility Information System (BFIS) using a forward chaining. Forward chaining method is a method for finding or techniques used for data tracking ahead to use existing information and to combine a rule to produce decision. The process of doing a forward chaining requires input variables. The input process include aspects of human and environmental aspects Management aspects of the marketing aspects of production and financial aspects. These variables are processed in a database which was later acquired data using inference machine to form a pattern of reasoning that is assembled using a forward chaining algorithm. The pattern of reasoning further registered into the database rule to get the address data. This research resulted in the Decision Support System (DSS) business viability with the calculation in the human resources aspect of 79.86, marketing at 75.24, 76.56 of the environment, the NPV of 86,167,498 and NPVir amounted to $255,686,953$, PI of 1.1 and an IRR of $29 \%$ from $25 \%$ rate.
\end{abstract}

Keywords : Business feasible study; Forward chaining; Inference machine; Decision support sistems (DSS).

\begin{abstract}
Abstrak
Pada penelitian ini telah dilakukan studi kelayakan bisnis pada sektor industri mikro. Penelitian ini didasarkan pada pentingnya Studi Kelayakan Bisnis (SKB) pada organisasi bisnis yang memerlukan penilaian kelayakan sebagai tolok ukur proses bisnis selain itu juga untuk meminimalisir resiko bisnis yang mungkin terjadi agar bisa ditanggulangi secara tepat. Penelitian ini bertujuan membuat Sistem Informasi Kelayakan Bisnis (SIKB) menggunakan forward chaining. Metode Forward chaining adalah metode untuk mencari atau teknik yang digunakan untuk pelacakan data ke depan menggunakan informasi yang ada dan menggabungan rule untuk menghasilkan kesimpulan. Proses dalam melakukan forward chaining membutuhkan variabel masukan. Proses masukan tersebut meliputi aspek SDM dan Manajemen aspek lingkungan aspek pemasaran aspek produksi dan aspek keuangan. Variabel tersebut diproses dalam database yang kemudian diakuisisi datanya menggunakan inference machine untuk membentuk pola penalaran yang dirangkai menggunakan algoritma forward chaining. Pola penalaran selanjutnya didaftarkan ke dalam database rule untuk mendapatkan alamat data. Penelitian ini menghasilkan Sistem Pendukung Keputusan (SPK) kelayakan bisnis dengan hasil perhitungan pada aspek SDM sebesar 79.86, pemasaran sebesar 75.24, lingkungan sebesar 76.56, NPV sebesar 86,167,498 dan NPVir sebesar 255,686,953, PI sebesar 1.1 dan IRR sebesar $29 \%$ dari rate $25 \%$.
\end{abstract}

Keywords : Studi kelayakan bisnis; Forward chaining; Inference machine; Sistem pendukung keputusan (SPK).

\section{Pendahuluan}

Dunia usaha yang semakin penting dalam menjalankan ekonomi Negara dengan semakin meningkatnya jumlah usaha mikro dan menengah menjadikan peluang untuk mengembangkan usaha disektor ini masih sangat terbuka, data dari kementrian UKM yang menunjukan jumlah usaha mikro dan menengah di Indonesia pada tahun 2014 masih 55.856.176 unit, menandakan masih sangat besar peluang kepada para investor untuk menginvestasikan dana mereka kedalam sektor UKM. (depkop.go.id, 2014).

Investasi memerlukan sebuah keputusan yang matang untuk menentukan apakah investor akan menanamkan modal atau tidak kepada perusahaan tersebut, investor juga memerlukan sebuah keputusan untuk menentukan apakah akan berinvestasi jangka

*) Penulis korespondensi: ddy.kurniadi@unissula.ac.id 
panjang, menengah atau pendek, memilih jenis investasi menjadi faktor paling utama dalam kegiatan bisnis, banyak hal yang dihadapi dalam sebuah usaha, perencaan yang matang dan ekstra menjadi hal yang mutlak.

Investor perlu cara yang benar untuk memperhitungkan resiko yang ditanamkan pada setiap investasi. Artinya lama pengembalian dari dana yang ditanamkan bisa kembali menjadi sangat penting, dalam hal ini sebelum investor menanamkan dananya ke usaha yang baru, perlu diketahui apakah investasi ini atau investasi yang akan dilakukan bisa mengembalikan dana dari investor dalam jangka waktu tertentu dan juga apakah investasi yang dijalankan memberikan dampak keuntungan finansial bagi investor (Stanley, 2011).

Perlu diadakan studi kelayakan bisnis terhadap perusahaan yang oleh investor akan diinvestasikan dananya dengan melakukan studi kelayakan bisnis, perlunya para pengusaha dan investor dalam melakukan kegiatan studi kelayakan bisnis adalah karena banyaknya perusahaan dalam lingkup usaha mikro dan menengah yang mengalami kerugian, tidak adanya pengawasan, tidak ada pengendalian sehingga membuat usaha tersebut berjalan dengan seadanya atas dasar itulah kelayakan bisnis perlu diadakan dan dibuat sebuah sistem informasi untuk mempermudah para investor maupun pengusaha dan pihak terkait dalam melakukan penilaian terhadap perusahaan tersebut.

Metode forward chaining merupakan solusi yang diterapkan untuk memberikan keputusan berdasarkan fakta yang ada, penelitian menggunkaan metode forward chaining dalam beberapa tahun terakhir sudah banyak dilakukan dan bertujuan untuk mengetahui bagaimana metode forward chaining memberikan solusi dan jawaban pada persoalan yang ada, penelitian menggunakan metode forward chaining diantaranya dilakukan pada area transportasi, penjadwalan, kesehatan, pertanian, pendidikan, logistik, bidang kedokteran, dan pemerintahan (Russel dan Norving, 2003).

Penelitian studi kelayakan bisnis ini menggunakan metode forward chaining yaitu metode dengan rule base yang bisa membantu memutuskan berdasarkan fakta - fakta yang ada, metode forward chaining seringkali digunakan untuk menyelesaikan sebuah masalah yang terkait dengan sistem pendukung keputusan, metode forward chaining adalah metode untuk mencari atau teknik yang digunakan untuk pelacakan data ke depan menggunakan informasi yang ada dan menggabungan rule untuk menghasilkan kesimpulan dan tujuan dari data yang dilacak (Russel dan Norving, 2003).

Dalam penelitian ini didalmnya juga terdapat metode forecasting dimana metode ini digunakan untuk mengetahui peramalan atau prakiraan produksi pada perusahaan tersebut, penggunaan metode forecasting dalam penelitian ini adalah berdasarkan deret waktu. Didasarkan pada urutan titik - titik data yang berjarak sama yaitu dalam jarak tahunan, kemudian untuk aspek SDM \& manajemen, lingkungan dan pemasaran menggunaan nilai index yang diperoleh menggunakan skala likert. Kemudian untuk aspek keuangan menggunakan metode Net Present Value, Payback Period, Profiatiblity Indeks, Internal Rate of Return, dan Maximum acceptable Rate of Return.

Kelebihan pada metode yang dimiliki oleh metode forward chaining adalah dalam melakukan pelacakan data dan proses akuisisi data yang mempunyai nilai dari masing-masing kriteria kemudian dilakukan rule evaluation kemudian dalam pelacakan data didapatkan kriteria yang bernilai true. yang akan diproses dengan inference engine untuk menghasilkan value yang sesuai dengan nilai yang dimasukkan.

\section{Kerangka Teori}

\subsection{Metode Forward Chaining}

Metode Forward chaining adalah metode untuk mencari atau teknik yang digunakan untuk pelacakan data ke depan menggunakan informasi yang ada dan menggabungan rule untuk menghasilkan kesimpulan dan tujuan dari data yang dilacak (Russel dan Norvig, 2003). Rule yang dapat dicari dengan Forward chaining seperti berikut :

1. Sistem dengan kondisi yang disajikan satu atau lebih.

2. Kondisi yang terdapat dalam sistem mencari rule dalam data knowledge yang berhubungan dengan function IF dan rule yang berkaitan.

3. Rule dalam forward chaining bisa menghasilkan kondisi baru dari kesimpulan awal pada THEN. Kemudian kondisi ini akan di store ke dalam data rulebase.

4. Sistem akan memproses setiap kondisi yang ditambahkan. Jika dalam sistem yang diproses terdapat kondisi baru dari kesimpulan maka sistem akan kembali mencari rule-rule dalam data knowledge.

Forward chaining ini sangat baik dengan sistem kerja membaca data yang sudah ada dan ingin mencapai tujuan akhir dengan goal yang sesuai harapan, karena metode ini memproses semua rangkaian data yang sudah ditentukan secara berurutan (Deepa et al., 2012).

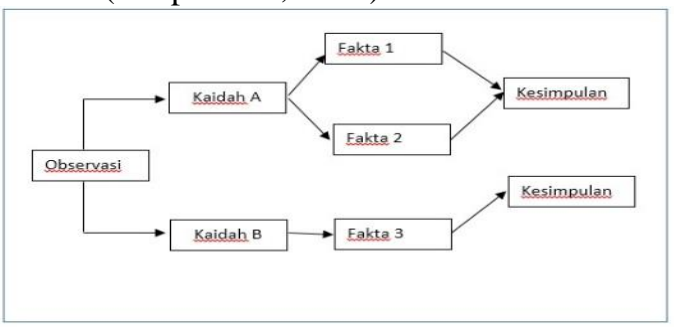

Gambar 1. Bagan forward chaining 
Forward chaining memproses data kemudian data diolah dengan komputasi mengikuti rule untuk mencapai tujuan akhir, metode ini memproses semua rangkaian data pada knowlegde base yang sudah diolah dan sudah ditentukan secara berurutan (Deepa dan Packiavathy, 2012).

Dalam forward chaining juga terdapat sebuah mesin yang sering kali dipanggil dengan sebutan inference machine atau mesin inferensi, dengan forward chaining mesin inferensi membentuk sebuah penalaran berdasarkan fakta yang bisa dirangkum kedalam rule (aturan) untuk menyimpulkan suatu solusi Mesin inferensi pada forward chaining dimulai dengan data yang tersedia dan digunakan sebagai aturan untuk mengambil data yang mempunyai nilai lebih sampai tujuan tercapai, bentuk logika dari forward chaining adalah jika ada klausa yang benar maka itu dijadikan kesimpulan sementara sehingga ada penambahan informasi baru untuk data (Lungu, 2009). Forward chaining, menjadikan mesin inferensi bisa membuat kesimpulan secara dedukasi, mengacu pada data fakta yang ada pada bagian kondisi suatu aturan.

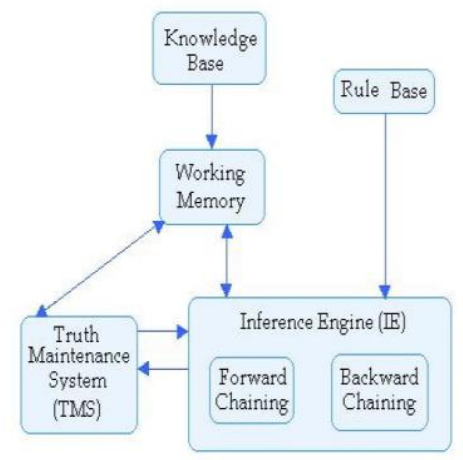

Gambar 2. Mesin Inferensi (Lungu, 2009)

Logika dari forward chaining adalah ketika bagian atau kondisi tersebut bernilai benar (true), maka aturan tersebut bisa digunakan. Kemudian yang selanjutnya fakta yang ada pada bagian yang disimpulkan dijadikan fakta baru yang sudah dikenal, dan fakta-fakta ini digunakan untuk menjalankan sebuah aturan-aturan yang saling berkaitan satu dengan yang lainnya dengan fakta tersebut ada didalamnya (Alasgarova dan Muradkhanli, 2008). Beberapa hal penting yang ada pada forward chaining dan berkaitan dengan sistem informasi pengambilan keputusan diantaranya adalah sebagai berikut :

1. Forward chaining merupakan teknik yang dikendalikan oleh data dan bisa juga disebut bahwa teknik ini adalah data driven.

2. Data fakta yang ada dan semua kemungkinan simpulan akan melalui pemrosesan secara deduktif.

3. Proses inferensi pada teknik forward chaining bisa terus digunakan selama aturan - aturan masih sesuai dan berlaku.
4. Bisa memberikan solusi atau pemecahan masalah dari berbagai sudut.

5. Untuk membuktikan hasil target, forward chaining membutuhkan teknik backward chaining.

\subsection{Sistem Pendukung Keputusan}

Sistem Pendukung Keputusan (SPK) atau Decision Support Systems (DSS) adalah perangkat lunak yang merekayasa knowledge yang dikodekan untuk troubleshooting secara khusus dan biasanya membutuhkan keahlian manusia untuk menyelesaikannya. Pengetahuan tersebut dikodekan ke dalam sistem yang di dalamnya ada inference machine dengan beberapa komponen (Nowduri, 2010). Gambar 3 menunjukkan komponen DSS.

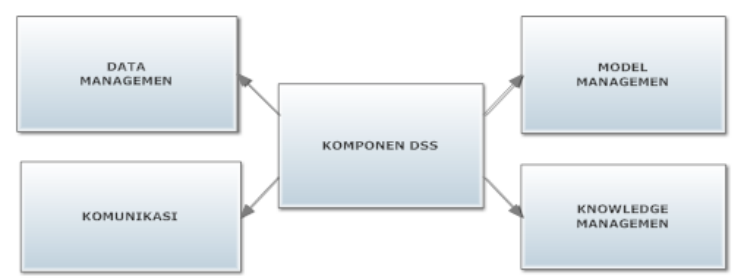

Gambar 3. Komponen DSS

Pengambilan keputusan adalah pemilihan tindakan-tindakan yang bersifat alternatif yang ada untuk menghasilkan satu atau beberapa tujuan yang telah ditetapkan (Turban, 2005). Sistem pendukung keputusan adalah suatu sistem yang berbasis komputer dimana sistem tersebut menghasilkan berbagai alternatif keputusan untuk digunakan oleh manajemen atau pimpinan dalam menghandel permasalahan yang terstruktur maupun tidak terstruktur dengan menggunakan data dan model (McLeod, 2004). komponen dari Sistem Pengambilan Keputusan (SPK) dapat dibangun berdasarkan subsistem seperti berikut:

1. Manajemen Data (Data Management), subsistem ini berbasis data yang relevan atau berkaitan dengan data awal yang diolah menggunakan software yang disebut Database Management System (DBMS).

2. Manajemen Model (Model Management), adalah seperangkat software yang relevan dengan modelmodel finansial, management science, statistik, dan kuantitatif, yang bisa memberikan analisa.

3. Manajemen Pengetahuan (Knowledge Management), subsistem berikut ini brsifat optional subsistem ini mendukung subsistemsubsistem lain dan bisa juga bertindak sebagai komponen yang berdiri sendiri (independent).

4. Antarmuka Pengguna (User Interface), subsistem antarmuka adalah subsistem yang digunakan atau dioperasikan oleh user untuk melihat sistem dan berkomunikasi dan digunaan untuk memerintah software. 
5. Pengguna (user), meliputi berbagai pengguna yang mengoperasikan software beberapa user di dalamnya, manager dan pengambil keputusan.

Komponen diatas memodelkan subsistem yang dipakai dalam manajemen sistem yang dibutuhkan dalam SPK (Turban, 2005).

\subsection{Proses Pengambilan Keputusan}

Proses pengambilan keputusan pada sistem informasi pada dasarnya berkaitan dengan proses pengumpulan, pengolahan, penyimpanan, dan transmisi informasi yang relevan untuk mendukung proses pengambilan di organisasi atau institusi manapun (Reddy et al., 2009 ).

Hasil dari sebuah keputusan bisa jadi adalah sebuah pernyataan yang disetujui antar alternative atau antar prosedur untuk mencapai tujuan tertentu. Pendekatan yang dapat dilakukan adalah dengan pendekatan yang bersifat individual atau kelompok, dengan hal itu proses pengambilan keputusan dibagi menjadi Decision Support System (DSS) dan Group Decision Support System (GDSS) kemudian juga dengan pendekatan sentralisasi dan disentralisasi, Persoalan pengambilan keputusan pada dasarnya adalah bentuk pemilihan dari berbagai alternative tindakan yang bisa saja tindakan tersebut dipilih, dan kemudian pada prosesnya melalui mekanisme tertentu yang ada pada organisasi tersebut, dengan harapan bahwa proses tersebut akan menghasilkan sebuah keputusan yang terbaik.

Model dibawah ini merupakan model yang menggambarkan bagaimana proses pengambilan keputusan itu diambil,

1. Intelligence: dalam fase ini intelligence merupakan proses penelusuran dan pendeteksian serta proses pengenalan dalam mengidentifikasi permasalahan, fase ini melakukan prosesing data dan pengujian data untuk mengidentifikasi masalah.

2. Design: dalam fase ini menjabarkan proses untuk menemukan, mengembangkan dan menganalisa alternatif tindakan yang bisa dilakukan. Pada tahap ini berbagai hal yang ada didalamnya adalah proses untuk mengerti masalah, memberikan solusi dan menguji kelayakan solusi.

3. Choice: merupakan proses pemilihan diantara berbagai alternatif yang tersedia yaitu tindakantindakan yang mungkin dijalankan dari hasil keputusan tersebut kemudian diimplementasikan dalam proses pengambilan keputusan

4. Implementation: tahap ini adalah tahap dimana keputusan yang telah diambil dilaksanakan, pada tahap ini perlu disusun serangkaian tindakan yang terstruktur dan terencana, sehingga hasil keputusan dapat dipantau dan disesuaikan dengan data dan informasi yang sebelumnya sudah dipaparkan.

Setelah mengetahui keempat tahapan proses pengambilan keputusan berbasis komputer, sistem bisa mengindentifikasi untuk proses pengambilan keputusan yang lebih baik (Suryadi, 2002).

Ada yang berpendapatan bahwa dalam fase atau tahap implementation dipandang perlu untuk dijadikan modul atau bagian yang terpisah hal tujuannya agar dalam penggambaran hubungan antar fase bisa dilakukan secara komprehensif tahapan tersebut ditunjukkan pada gambar 4 .

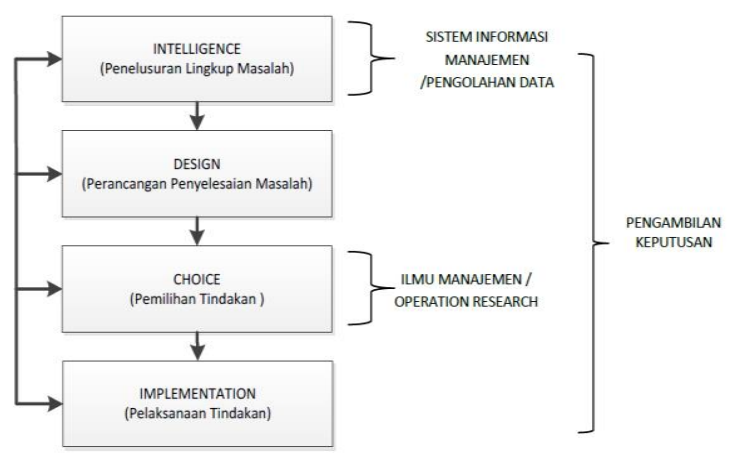

Gambar 4. Pengambilan Keputusan (Suryadi, 2002)

\subsection{Pengertian Studi Kelayakan Bisnis}

Studi kelayakan bisnis adalah penelitian yang bertujuan untuk memutuskan apakah bisnis tersebut layak dan bisa memberikan manfaat kepada pihak pihak yang terkait (investor dan pelaku bisnis) dari kegiatan usaha tersebut atau dinilai tidak layak dan tidak ada manfaat dalam kegiatan bisnis tersebut (Suliyanto, 2010).

Studi kelayakan bisnis adalah penelitian yang menyangkut berbagai aspek, beberapa diantaranya aspek Hukum, Lingkungan, SDM dan Manajemen, Pemasaran, Produksi sampai dengan Keuangan aspek tersebut merupakan landasan untuk mengambil sebuah keputusan dan menentukan bisnis tersebut layak untuk dijalankan, ditunda atau tidak layak sama sekali untuk dijalankan (Suliyanto, 2010).

Setiap bisnis memerlukan adanya studi kelayakan bisnis pada saat memulai usahanya ataupun dalam mengembangkan usahanya meskipun intensitas yang digunakan berbeda - beda. Intensitas pada penyusunan studi kelayakan bisnis tergantung pada hal berikut :

1. Besar kecilnya dampak yang dapat ditimbulkan oleh studi kelayakan bisnis tersebut, semakin besar dampak yang diberikan atau ditimbulkan dari bisnis tersebut semakin tinggi kecermatan yang diperlukan dalam menyusun studi kelayakan bisnis. Sebaliknya jika semakin kecil dampak yang diberikan atau ditimbulkan dari kegiatan bisnis tersebut maka semakin rendah tuntutan kecermatan dalam menyusun studi kelayakan bisnis tersebut.

2. Besar kecilnya tingkat kepastian dalam bisnis tersebut, semakin besar tingkat kepastian yang diberikan oelh suatu kegiatan bisnis semakin 
tinggi intensitas dalam menyusun studi kelayakan bisnis tersebut begitu juga sebaliknya apabila kepastian yang diberikan rendah maka intensitas tuntutan dalam menyusun kelayakan bisnis juga rendah.

3. Banyak sedikitnya investasi yang diperlukan untuk melaksanankan suatu kegiatan bisnis, semakin besar nilai investasi yang ditanamkan pada kegiatan bisnis semakin tinggi kecermatan yang diperlukan dalam menyusun studi kelayakan bisnis, hal sebaliknya juga berlaku jika nilai investasi rendah semakin sederhana studi kelayakan yang perlu dilakukan.

\subsection{Langkah - Langkah Studi Kelayakan Bisnis}

Studi kelayakan bisnis adalah metode ilmiah yang digunakan untuk penyusunan penilaian bisnis, metode ilmiah harus bersifat sistematis (Suliyanto, 2010), untuk penyusunan studi kelayakan bisnis meliputi berbagai langkah kegiatan. Penyusunan secara umum ditunjukkan pada gambar 5.

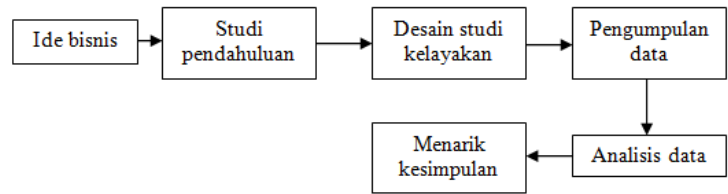

Gambar 5. Langkah-langkah SKB (Suliyanto, 2010)

1. Ide Bisnis.

Ide bisnis adalah wacana seseorang untuk melakukan bisnis atau mengembangkan bisnis, ide bisnis ini muncul karena sebuah peluang yang dipandang memiliki prospek yang baik.

2. Melakukan Studi Pendahuluan.

Studi pendahuluan dilakukan untuk memperoleh gambaran umum atau proyeksi dari peluang bisnis dari ide bisnis yang sudah diwacanakan, termasuk didalamnya prospek dan kendala apa saja yang kira-kira akan dihadapi, jika dari studi pendahuluan sebuah ide bisnis memiliki kendala yang cukup besar maka perlu dipertimbangkan ide bisnis tersebut, sebaliknya jika prospek bisnis menjanjikan dengan kendala yang lebih kecil maka ide bisnis sangat layak.

3. Membuat Desain Studi Kelayakan.

Setelah gambaran umum tentang peluang bisnis dari ide bisnis yang akan dijalankan diperoleh lengkah selanjutnya adalah membuat desain studi kelayakan bisnis yang meliputi aspek-aspek yang sudah ditentukan.

4. Pengumpulan Data.

Pengumpulan data dapat dilakukan dengan menggunakan observasi, wawancara maupun kuesioner sedangkan sumber data dapat berupa data primer atau sekunder.

5. Analisa Data.

Analisa data dapat dilakukan dengan analisis kualitatif maupun kuantitatif
6. Menarik Kesimpulan

Kesimpulan didasarkan pada hasil analisis data untuk memutuskan suatu ide bisnis layak untuk dijalankan atau tidak berdasarkan penilaian dari berbagai aspek yang ada pada studi kelayakan bisnis tersebut.

\subsection{Aspek - Aspek Penilaian}

Aspek - aspek yang digunakan untuk membantu sistem pendukung keputusan dalam menyelesaikan permasalahan diantaranya :

1. Aspek Yuridis (Hukum)

Dalam kelayakan bisnis, aspek hukum sangat penting mengingat usaha yang dijalankan harus memenuhi persyaratan dokumen yang legal. Aspek ini sangat diperlukan terutama bagi investor selaku pemrakarsa.

2. Aspek Produksi

Aspek ini bertujuan untuk menentukan hasil produksi atau volume produksi yang bisa diproduksi oleh perusahaan dan jumlah permintaan yang diminta. Penilaian aspek produksi menggunakan metode forecasting, forecasting adalah metode prediksi yang digunakan untuk menentukan jumlah barang atau stock dan permintaan terhadap barang atau demand (Weron,2014).

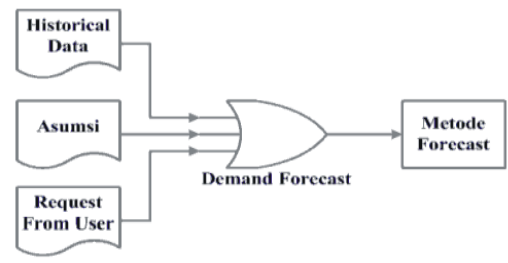

Gambar 6. Proses Forecasting

3. Aspek SDM \& Manajemen Aspek manajemen merupakan aspek penting dalam kelayakan bisnis, dalam aspek SDM dan Manajemen ada 4 hal untuk memenuhi kelayakan bisnis, Kepemilikan , Organisasi, Tim manajemen dan Karyawan.

4. Aspek Pemasaran

Sebelum perusahaan didirikan atau akan mengembangkan perusahaan baru investor harus tau betul kondisi kebutuhan pasar untuk usaha tersebut.

5. Aspek Lingkungan

Merupakan elemen kegiatan bisnis dari suatu orgaisasi yang berinteraksi dengan lingkungan tempat dimana bisnis tersebut dijalankan.

6. Aspek Keuangan

Aspek keuangan merupakan hal yang sangat vital karena berkaitan dengan pemasukan dan pengeluaran dari kegiatan bisnis, penilaian aspek keuangan bisa dilakukan dengan metode dibawah ini :

a. Net present value (NPV) adalah penilaian invetasi yang sering digunakan untuk 
mengukur suatu usaha yang akan dijalankan layak (feasible) atau tidak.

b. Internal rate of return (IRR) adalah discount rate untuk menghasilkan NPV (Net Present Value).

c. Profitability Indeks (PI), adalah rasio dari aktifitas jumlah nilai dari penerimaan bersih dan nilai pengeluaran investasi

d. Payback period (PBP) adalah jangka waktu tertentu dalam periode yang menunjukan cash in flow secara kumulatif sama dengan jumlah investasi dalam bentuk present value investasi.

e. Maximum acceptable rate of return (MARR) adalah laju pengembalian maksimal dari suatu investasi yang dilakukan oleh investor.

Berdasarkan dari penjabaran enam parameter penilaian aspek kelayakan bisnis maka didapatkan rumus atau aturan untuk memberikan penilaian yang bisa dibentuk dalam sistem pengambilan keputusan (Hasan, 2012). Adapun rumus yang digunakan adalah sebagai berikut

$$
\mathrm{NPV}=C F 0+\frac{C F 1}{1+Y}+\frac{C F 2}{(1+\eta)^{2}}+\cdots \frac{C F t}{(1+\eta)^{\mathrm{t}}}
$$

Dimana :

$$
\begin{array}{ll}
\text { NPV } & : \text { Net Present Value } \\
\text { CFO } & : \text { CashFlow ke-n } \\
C F t & : \text { Waktu Arus Kas } \\
r & : \text { Suku Bunga }
\end{array}
$$

$$
\mathrm{PI}=\frac{\text { inv-npw }}{\text { inv }}
$$

Dimana :

PI : Profitability Index

inv : Nilai Investasi

NPV : Net Present Value

$$
\mathrm{PBP}=j w+\left(i n v-\left(\frac{C F 1+C F 2+C F a+C F 4}{C F 5}\right)\right)
$$

Dimana :

PBP : Payback Periode

jw : Jangka Waktu

inv : Nilai Investasi

CF : Aliran Arus Kas Tahunan

Dimana :

$$
\mathrm{IRR}=I r+\frac{\mathrm{NPV} I Y}{\text { NPV Ir-NPVIt }} *(I t-I r)
$$

$$
\begin{array}{ll}
\text { IRR } & : \text { Internal Rate of Return } \\
\text { Ir } & : \text { Suku Bunga Rendah } \\
\text { NPV Ir } & : \text { NPV Bunga Rendah } \\
\text { NPV It } & : \text { NPV Bunga Tinggi } \\
\text { It } & : \text { Bunga Tinggi }
\end{array}
$$

Dari rumus diatas kemudian disimpan sebagai data fakta yang kemudian akan diolah dan dialamatkan datanya sehingga mendapatkan value yang kemudian diproses menggunakan algoritma forward chaining menggunakan rumus 5 .

$$
R=\left\{\begin{array}{l}
R i 1=\{j \mid a i j=1\} \\
R i 2=\{j \mid a i j=2\} \\
F j 1=\{i \mid a i j=1\} \\
F j 2=\{i \mid a i j=2\}
\end{array}\right.
$$

Dimana :

Ri : Rule Row

a : Nilai Tiap Aspek

Fj : Fakta Row

$i \quad$ : Keanggotaan $i$ Pada Variabel $a$

$R \quad$ : Nilai Rule

$j \quad$ : Keanggotaan $j$ Pada Variabel $a$

\subsection{Rule Base Forward chaining}

Rule base untuk menentukan kombinasi awal dalam menentukan kelayakan (feasible) kegiatan bisnis ditunjukkan pada tabel 1 .

Tabel 1. Rule Base

\begin{tabular}{lll}
\hline Kondisi & Kombinasi & Kesimpulan \\
\hline If & A,B,C,D,E,F & Layak \\
Else if & A,B,C,D,E & Tidak layak, revisi aspek F \\
Else if & A,B,C,D,F & Tidak layak, revisi aspek E \\
Else if & A,B,C,E,F & Tidak layak, revisi aspek D \\
Else if & A,B,D,E,F & Tidak layak, revisi aspek C \\
Else if & A,C,D,E,F & Tidak layak, revisi aspek B \\
Else if & B,C,D,E,F & Tidak layak, revisi aspek A \\
\hline
\end{tabular}

Dari rule diatas kemudian disesuaikan dengan rumus kuesioner, rumus kuesioner yang digunakan adalah skala likert dengan skala 1 sampai dengan 5 adapun skalanya adalah sebagai berikut
1. Sangat rendah
2. Rendah
3. Cukup
4. Tinggi
5. Sangat tinggi

Adapun rumus index adalah sebagai berikut :

Skor $=\frac{(96 F 1 \times 1)+(96 F 2 \times 2)+\ldots+(96 F 5 \times 5)}{n}$

Dimana :

Skor : Nilai dari Index

$\% F \quad$ : Jumlah Skala

n : Nilai Maksimum Untuk Pembagi

Algoritma forward chaining dalam implementasi

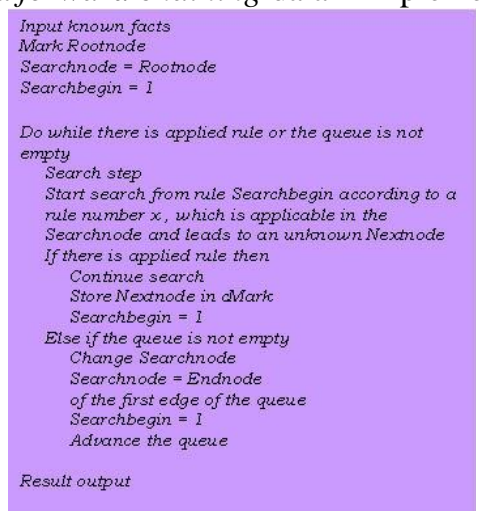

Gambar 7. Forward Chaining (Erdani, 2011) 


\section{Metodologi}

\subsection{Prosedur Penelitian}

Dalam penelitian ini dimulai dengan melakukan identifikasi masalah dan didukung dengan studi pustaka, Untuk memastikan agar analisis yang dilakukan oleh sistem akan mencapai hasil yang maksimal dan memberikan informasi yang akurat dan objektif. Secara garis besar ada berbagai tahapan yang dilakukan dalam penelitian ini tahapan tersebut seperti pada gambar 8 .

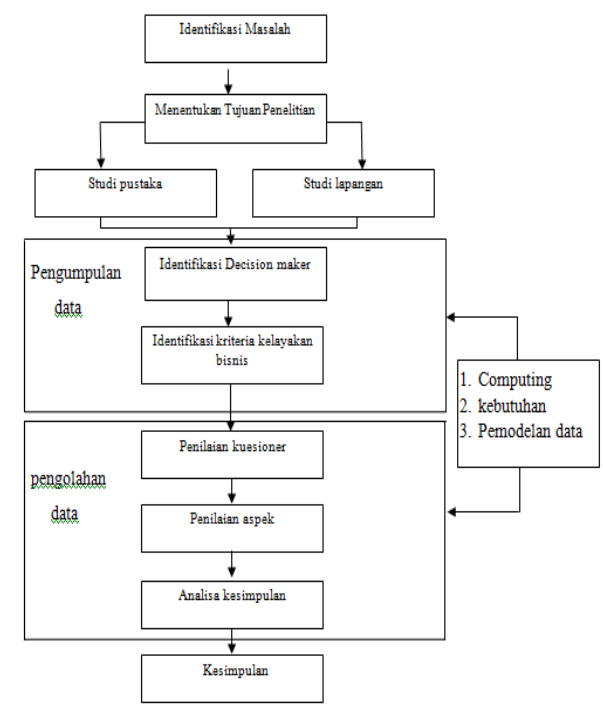

Gambar 8. Prosedur Penelitian

1. Identifikasi Masalah,

Pada tahap ini dilakukan identifikasi kriteria kriteria apa saja yang dipakai untuk mengukur tingkat kelayakan bisnis, melakukan model analisis yang tepat dan sesuai untuk digunakan mengukur kriteria - kriteria tersebut baik secara kualitatif maupun kuantitatif, yang berguna sebagai pendukung keputusan atau kebijakan maupun rekomendasi yang berkaitan dengan kelayakan bisnis pada perusahaan tersebut, dalam identifikasi juga terdapat perumusan masalah, tahap perumusan masalah dilakukan setelah mengidentifikasi masalah yang akan diselesaikan, tujuan dari penelitian ini adalah mengembangkan sistem informasi kelayakan bisnis untuk mengambil keputusan apakan ide bisnis layak untuk dijalankan atau tidak dan juga untuk memberikan manfaat kepada pihak - pihak terkait agar mendapatkan manfaat dari sistem inforasi kelayakan bisnis ini. Studi literatur dilakukan dengan cara mengumpulkan jurnal berskala internasional maupun nasional, artikel - artikel penelitian dan berbagai buku.

2. Pengumpulan Data

Pada tahap pengumpulan data diawali dengan mengidentifikasi pihak - pihak yang terkait dengan studi kelayakan bisnis yang merupakan pelaku dari kegiatan bisnis, kriteria pengumpulan data adalah dengan melakukan wawancara dan kuesioner, serta juga dengan menggunakan data historical seperti laporan keungan tahunan, jumlah nilai investasi.

3. Kebutuhan Fungsional dan Non Fungsional Tahap kebutuhan fungsional dan non fungsional ini berkaitan dengan kebutuhan apa saja yang kira - kira mendukung untuk memperkaya data yang sudah dilakukan di tahap pengumpulan data, tahap ini mengidentifikasi ketika data sudah dikumpulkan kemudian kebutuhan apa saja yang akan digunakan untuk menganalisa data tersebut.

4. Proses Pemodelan Data

Pada tahap ini proses pemodelan data dengan data yang sudah dikumpulkan kemudian data diproses dengan metode Net Present Value, Internal Rate Return, Profitability Index, Payback Period, Maximum acceptamble rate of return untuk mendapatkan penilaian kemudian setelah pemodelan tersebut memberikan hasil hasil tersebut dimasukan kedalam rule base forward chaining sebagai metode pendukung keputusan untuk mendapatkan hasil keputusan yang sudah diolah secara komputerisasi dengan sistem informasi kelayakan bisnis, dalam tahap ini ada dua langkah yang dilakukan yaitu penilaian dari berbagai aspek yang sudah ditentukan diatas dan perhitungan menggunakan rumus dari rumus berbagai aspek tersebut, pada tahap penghitungan dilakukan penghitungan dari berbagai aspek sehingga menghasilkan skor untuk kemudian akan diambil keputusan berdasarkan fakta yang ada pada informasi tersebut dengan berbasis pengetahuan (knowledge) dan aturan (rule).

5. Analisa Keputusan

Tahap ini melakukan analisa keputusan yang sudah diambil dan disajikan kepada user untuk memberikan keputusan atau rekomendasi tentang kelayakan bisnis perusahaan tersebut, didalam tahap ini ditampilkan hasil-hasil dari aspek aspek yang sudah dinilai kemudian disajikan kepada user atau pihak - pihak terkait dengan kegiatan bisnis tersebut.

6. Kesimpulan

Pada tahap ini setelah analisa keputusan dilakukan maka kesimpulan dan saran diambil dengan menggunakan metode forward chaining yang mengambil data dari database dengan field rule_base ang didalamnya sudah disediakan berbagai keputusan dan kesimpulan yang dibedakan dengan id dari field tabel tersebut.

Pada tahap ini dilakukan identifikasi kriteriakriteria apa saja yang dipakai untuk mengukur tingkat kelayakan bisnis, melakukan model analisis yang tepat dan sesuai untuk digunakan mengukur kriteria-kriteria tersebut baik secara kualitatif maupun kuantitatif. Pada tahap pengumpulan data diawali dengan mengidentifikasi pihak-pihak yang terkait dengan studi kelayakan bisnis yang 
merupakan pelaku dari kegiatan bisnis. Tahap kebutuhan fungsional dan non fungsional ini berkaitan dengan kebutuhan apa saja yang kira-kira mendukung untuk memperkaya data yang sudah dilakukan di tahap pengumpulan data. Pada proses pemodelan data dengan data yang sudah dikumpulkan kemudian data diproses dengan metode Net Present Value, Internal Rate Return, Profitability Index, Payback Period, Maximum acceptamble rate of return untuk mendapatkan penilaian kemudian setelah pemodelan tersebut memberikan hasil. Tahap ini melakukan analisa keputusan yang sudah diambil dan disajikan kepada user untuk memberikan keputusan atau rekomendasi tentang kelayakan bisnis perusahaan tersebut. Setelah analisa keputusan dilakukan maka kesimpulan dan saran diambil dengan menggunakan metode forward chaining yang mengambil data dari database dengan field rule_base yang didalamnya sudah disediakan berbagai keputusan dan kesimpulan.

Tahapan implementasi program dan pengkodean kedalam sistem yang merupakan tahapan untuk menterjemahkan logika kedalam diagram alir ditunjukan pada gambar 9 .

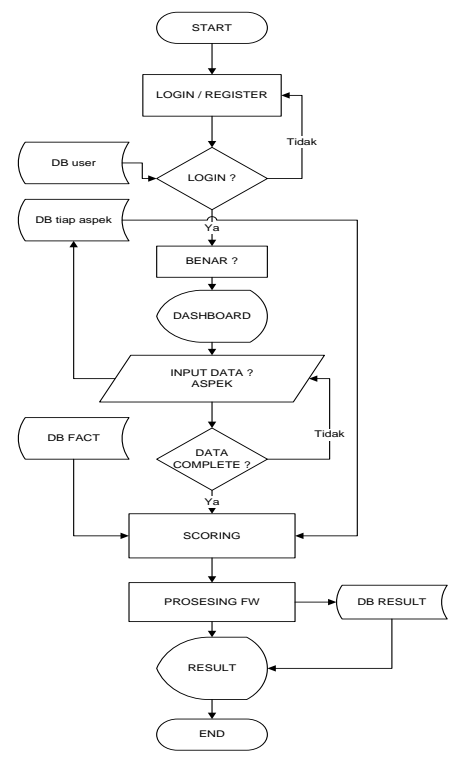

Gambar 9. Flowchart Sistem

\section{Hasil dan Pembahasan}

Penelitian ini menghasilkan sebuah Sistem Pendukung Keputusan (SPK) untuk menentukan kelayakan bisnis pada sektor industri mikro, di mana sistem ini memberikan penilaian yang ditampilkan pada dashboard. Hasil penilaian dan advice dari sistem tersebut bisa digunakan sebagai bahan masukan kepada investor, pemilik usaha dan para pelaku bisnis di sektor industri mikro untuk bisa digunakan sebagai alternatif kebijakan pengambilan keputusan dalam organisasi bisnis tersebut, seperti pengembangan sektor bisnis atau pembukaan bisnis baru pada sektor industri tersebut. Semua informasi pada sistem ini terpusat pada halaman dashboard yang didalamnya terdapat hasil penilaian dari berbagai aspek yang ditunjukan dengan grafik yang mana bisa dilihat pada gambar 10 .

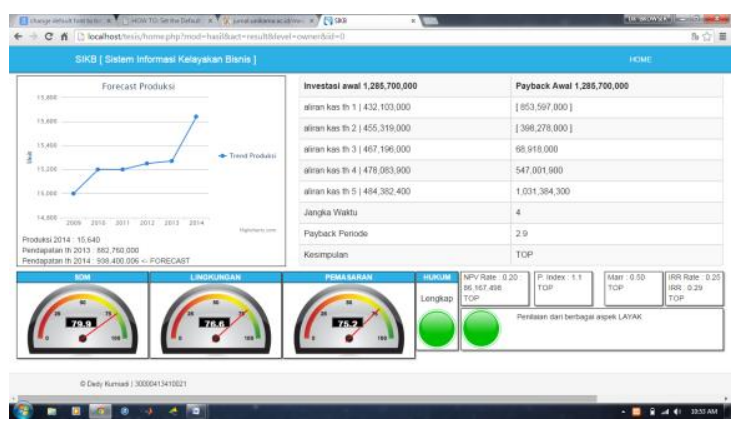

Gambar 10. Dashboard Sistem Kelayakan Bisnis

Setelah dilakukan pengujian terhadap sistem, beberapa hasil dari berbagai aspek dapat dilihat dari dashboard ditunjukkan pada gambar 11.

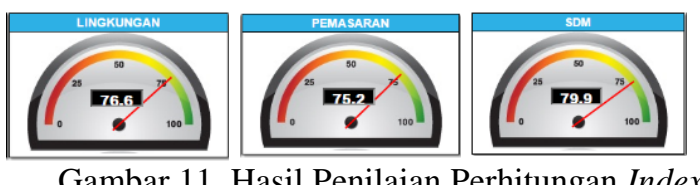

Gambar 11. Hasil Penilaian Perhitungan Index

Kemudian dua aspek yaitu aspek produksi dan keuangan ditampilkan dalam dashboard yang menunjukkan grafik perhitungan dari sistem bisa dilihat pada gambar 12 .

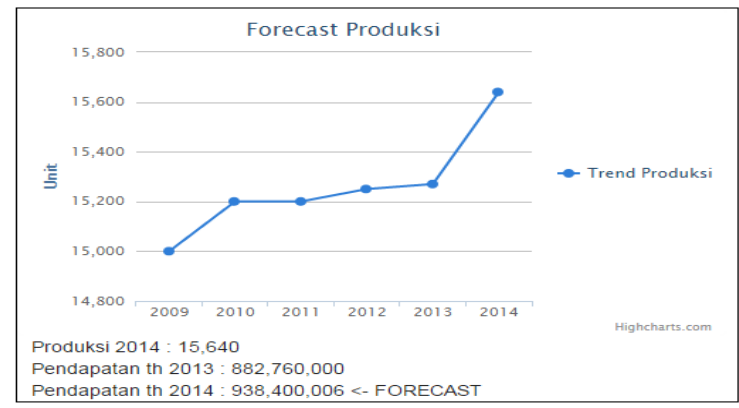

Gambar 12. Grafik Forecasting

Pada aspek produksi menggunakan metode forecasting, sehingga bisa diketahui hasil dari produksi untuk tahun berikutnya. Dan untuk aspek keuangan bisa dilihat pada gambar 13.

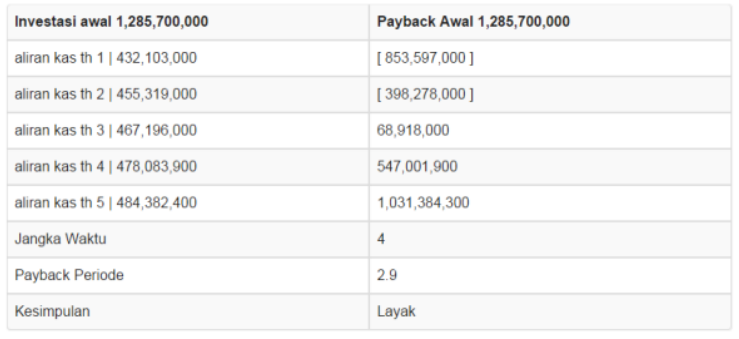

Gambar 13. Hasil Perhitungan PBP 
Melakukan verifikasi perhitungan manual dan kemudian di komparasi dengan sistem berdasarkan pengolahan data. Pada tahap ini dilakukan penghitungan menggunakan sistem.

Perhitungan tiap aspek menggunakan rumus index untuk menentukan besaran nilai dari tiap aspek perhitungan dengan menggunakan perumusan manual menggunakan rumus seperti berikut :

$$
\text { Skor }=\frac{(\% F 1 x 1)+(\% F 2 x 2)+\ldots+(\% F 5 x 5)}{n}
$$

Perhitungan pada aspek lingkungan menggunakan rumus index menghasilkan point seperti pada tabel 2. Tabel 2. Perhitungan Aspek Lingkungan

\begin{tabular}{|c|c|c|c|c|c|c|c|c|}
\hline No & Aspek Peniliaian & 1 & 2 & 3 & 4 & 5 & Point & \\
\hline 1 & Kondisi persaingan antar perushasan & 0 & 0 & 1 & 2 & 0 & 72.6 & \\
\hline 2 & Kondisl lingkkngan pemasok & 0 & 0 & 1 & 2 & 0 & 72.6 & \\
\hline 3 & Kondisi lingkungan pelanggan & 0 & 0 & 1 & 2 & 0 & 72.6 & \\
\hline 4 & Kondisi lingkungan barang subtitusi & 0 & 0 & 2 & 1 & 0 & 66 & \\
\hline 5 & Kondisi lingkungan hambatan masuk & 0 & 0 & 1 & 2 & 0 & 72.6 & \\
\hline 6 & Kondisil lingkkngan ekonomi & 0 & 0 & 1 & 2 & 0 & 72.6 & \\
\hline 7 & Kondisi lingkkungan sosial budaya & 0 & 0 & 1 & 2 & 0 & 72.6 & \\
\hline 8 & Kondisi lingkungan dengan teknologi & 0 & 0 & 0 & 1 & 2 & 92.4 & \\
\hline 9 & Kondisi harga bahan baku & 0 & 0 & 0 & 2 & 1 & 85.8 & \\
\hline \multirow[t]{2}{*}{10} & Tingkat ketersediaan bahan baku & 0 & 0 & 0 & 2 & 1 & 85.8 & \\
\hline & HASIL. & & & & & & 76.56 & Tinggi \\
\hline
\end{tabular}

Dari tabel 2 terlihat hasil dari perhitungan rumus index pada aspek lingkungan yaitu dengan sepuluh kriteria dihasilkan point 76.56 kriteria tersebut masuk kedalam rata-rata nilai tinggi.

Selanjutnya pada aspek pemasaran, pada aspek ini masih menggunakan rumus index tabel 3 menunjukkan hasil perhitungan dari aspek pemasaran

Tabel 3. Perhitungan aspek pemasaran

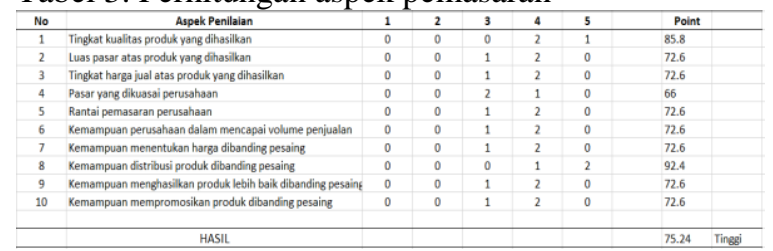

Dari perhitungan menggunakan rumus index diketahui hasil dari perhitungan aspek pemasaran adalah 75.24.

Pada tabel 3 menunjukkan perhitungan aspek SDM dan Manajemen, pada aspek ini data yang diambil adalah tata kelola dari organisasi.

Tabel 3. Perhitungan Aspek SDM dan Manajemen

\begin{tabular}{|c|c|c|c|c|c|c|c|}
\hline No & Aspek Penilalä & 1 & 2 & 3 & 4 & 5 & Point \\
\hline 1 & Perushahan memiliki iokumen hulum lengkap & $a$ & 0 & 1 & 2 & $a$ & 72.6 \\
\hline 2 & Perushazan memiliki izin usha lenghap & $a$ & 0 & 1 & 2 & 0 & 726 \\
\hline 3 & Skalla pervsahhan & $a$ & 0 & 1 & 2 & 0 & 72.6 \\
\hline 4 & sistempengelollaan perusahaan & a & 0 & 1 & 2 & a & 72.6 \\
\hline 5 & Tingkhat kompenssasis yang diberikan & $a$ & 0 & 1 & 2 & 0 & 72.6 \\
\hline 6 & Kemampuan merekkut tenaga kerja sesuai jobdesc & $a$ & 0 & 0 & 2 & 1 & 85.8 \\
\hline$T$ & Ketersediaan tenaga keria untuk menjjalankan bisnis & a & 0 & 0 & 2 & 1 & 85.8 \\
\hline 8 & 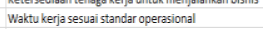 & $a$ & 0 & 0 & ${ }_{1}^{2}$ & 2 & 92.4 \\
\hline 9 & Tingkat kinerj, pegawai & 0 & 0 & 0 & $\frac{1}{2}$ & 1 & $\begin{array}{l}824.8 \\
85.8\end{array}$ \\
\hline 10 & Alurkeria dalam pervsshasan & a & 0 & 0 & 2 & 1 & 85.8 \\
\hline
\end{tabular}

Pada aspek SDM dan Manajemen diketahui jumlah perhitungan menghasilkan point sebesar 79.86.

Kemudian perhitungan pada aspek keuangan meliputi empat parameter diantaranya adalah :

1. Perhitungan PBP
Perhitungan pada parameter PBP mennghitung inflow dari tahun ke 0 - tahun ke n rumus perhitungannya menggunakan rumus fungsi PBP Gambar 14 menunjukkan perhitungan PBP dari tahun ke 0 sampai tahun ke 5 dengan menggunakan rumus fungsi PBP.

\begin{tabular}{|c|c|c|c|c|}
\hline Tahun & \multicolumn{2}{|c|}{ Kumulatif Aliran Kas } & \multicolumn{2}{|c|}{ payback awal } \\
\hline & 0 IDR & $(1,285,700,000)$ & IDR & $1,285,700,000$ \\
\hline & $1 \mathrm{IDR}$ & $432,103,000$ & IDR & $(853,597,000)$ \\
\hline & $2 I D R$ & $455,319,000$ & IDR & $(398,278,000)$ \\
\hline & 3 IDR & $467,196,000$ & IDR & $68,918,000$ \\
\hline & 4 IDR & $478,083,900$ & IDR & $547,001,900$ \\
\hline & 5 IDR & $484,382,400$ & IDR & $1.031 .384,300$ \\
\hline
\end{tabular}

Gambar 14. Hasil Perhitungan Rumus Fungsi PBP Dari rumus perhitungan PBP didapatkan hasil pada tahun ke-3 arus pengembalian positif artinya arus pengembalian lebih kecil dari jangka waktu yang dicanangkan.

2. Perhitungan NPV

NPV dihitung menggunakan data cashflow penghitungan NPV akan menghasilkan NPV bunga tinggi dan NPV bunga rendah yang digunakan untuk mencari nilai internal rate of return (IRR). Dari perhitungan NPV dihasilkan nilai NPV sebesar 86,167,498 dan NPVir sebesar 255,686,953 baik NPV maupun NPVir keduaduanya menunjukan NPV berada pada posisi positif.

3. Perhitungan Profitability Index

Perhitungan profitability index seperti diketahui menggunakan rumus fungsi PI dari hasil perhitungan profitability index (PI) dihasilkan bahwa posisi PI adalah sebesar 1.1 itu artinya profitability index dinyatakan layak karena posisinya masih lebih dari 1, kelayakan profitability index adalah PI $>1$.

4. Perhitungan IRR

Perhitungan IRR adalah menghitung Internal Rate of Return (IRR) dari dua NPV dengan NPV bunga tinggi dan NPV bunga rendah, NPV bunga tinggi adalah NPVit $=86,167,498$ dan NPV untuk bunga rendah adalah NPVir $=255,686,953$ dari perhitungan rumus IRR didapatkan hasil adalah sebesar 29\% itu artinya IRR dikatakan layak karena IRR lebih besar dari rate yang ditetapkan yaitu sebesar $25 \%$.

Hasil dari perhitungan tersebut kemudian dimasukkan kedalam database yang kemudian diolah oleh sistem menggunakan forward chaining dimana data yang diolah adalah data tahunan yang disajikan oleh sistem seperti pada gambar 15 .

\begin{tabular}{|r|c|c|c|c|c|}
\hline No & Tahun & Produksi & Permintaan & Harga / potong & Pendapatan \\
\hline 1 & 2009 & 15000 & 14900 & IDR 53,000 & IDR $789,700,000$ \\
\hline 2 & 2010 & 15200 & 15020 & IDR 55,000 & IDR $826,100,000$ \\
\hline 3 & 2011 & 15200 & 15150 & IDR 56,000 & IDR $848,400,000$ \\
\hline 4 & 2012 & 15250 & 15230 & IDR 57,000 & IDR $868,110,000$ \\
\hline 5 & 2013 & 15270 & 15220 & IDR 58,000 & IDR $882,760,000$ \\
\hline
\end{tabular}

Gambar 15. Perhitungan Sistem 
Kemudian sistem mengolah data sumber pada gambar 15 menjadi tiap aspek yang ditampilkan dalam dashboard sistem.

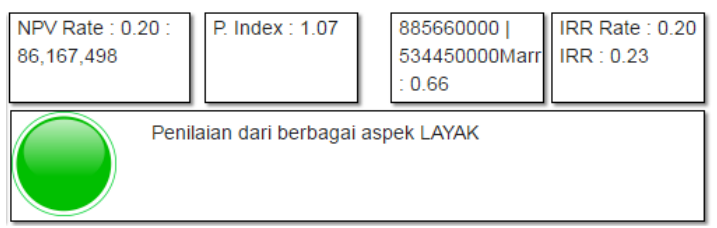

Gambar 15. Perhitungan Sistem Tiap Aspek

Perhitungan sistem yang menampilkan hasil tiap aspek menunjukkan bahwa nilai NPV, PI, IRR dan MARR menunjukan tanda hijau yang artinya memenuhi kriteria layak sepeti pada NPV nilai berada pada titik positif yang artinya menunjukan trend meningkat, kemudian pada PI angkanya menunjukkan diatas 1 menandakan bahwa profit yang dihasilkan layak, selanjutnya pada MARR menunjukkan angka yang positif dan kemudian pada IRR dimana hasil dari IRR diatas dari rate yang sudah ditentukan hasil tersebut berarti nilai return layak sehingga dari hasil perhitungan secara keseluruhan aspek menandakan bahwa perhitungan sistem memberikan hasil layak.

\section{Kesimpulan}

Berdasarkan hasil penelitian dan analisa hasil penelitian dapat diambil beberapa kesimpulan diantaranya yaitu :

1. Penggunaan mesin inferensi untuk mendukung kinerja dari algoritma forward chaining lebih baik dalam mengolah data yang terdapat dalam database dimana terdapat banyak data yang diolah secara bersamaan.

2. Sistem pendukung keputusan menggunakan metode forward chaining dengan variabel masukan dapat menghasilkan penilaian terhadap kelayakan bisnis sebagai referensi kepada para pengusaha dan investor.

3. Hasil dari sistem ini telah diuji dan diverifikasi, dari penelitian dan analisa menunjukan bahwa sistem pendukung keputusan kelayakan bisnis dengan metode forward chaining menghasilkan output yang sama dalam segi perhitungan dengan kondisi real perusahaan yang dinilai.

4. Metode forward chaining dengan menggunakan mesin inferensi mempengaruhi kecepatan dalam olah data, sehingga memberikan efisiensi dalam penggunaan sistem dari segi waktu dan space dari database.

\section{Ucapan Terima Kasih}

Ucapan terima kasih sebesar-besarnya disampaikan kepada pemilik, investor dan karyawan CV. Inda Jaya Pemalang serta segenap pihak yang terkait yang telah memberikan kontribusi sehingga penelitian ini berhasil diselesaikan dengan baik.

\section{Daftar Pustaka}

Alasgarova, A., dan Muradkhanli, L., 2008. Expert systems for decision-making problem in economics, International Journal of Information Technologies and Knowledge (2), 297-299.

Deepa, S.T., dan Packiavathy, S.G., 2012. Expert systems for car troubleshooting, International Journal for research in science \& advance technologies 1 (1), 46-49.

Erdani, Y., 2011. Developing recursive forward chaining method in ternary grid expert systems, Intenational Journal of Computer Science and Network 11 (8), 126-130.

Hasan, M., 2013. Capital budgeting techniques used by small manufacturing companies, Journal of Service Science and Management (6), 38-45.

Lungu, V., 2009. Rule-based systems for emotional decision making agent. International Journal of Computer Science and Engineering (1), 1-3.

McLeod, R., 2004. Management Information Systems, New Jersey, Prentice Hall.Inc.

Nowduri, S., 2010. Management information systems and business decision making: review, analysis, and recommendation, International Journal of Management and Marketing Research (1), 1-8.

Puspayoga, A.G., 2014. Pusat Data dan Informasi Jumlah UMKM di Indonesia, Website : http://depkop.go.id/data-jumlah-umkm.htm, diakses tanggal : 15 Februari 2015.

Russel, S., dan Norving, P., 2003. Artificial Intelligence - A Modern Approach, New Jersey, Prentice Hall.Inc.

Stanley, M., 2011. Investment Management Journal, New York, NY.

Suliyanto, S., 2010, Studi Kelayakan Bisnis Pendekatan Praktis, Yogyakarta, PT.Andi.

Suryadi, K., 2002. Sistem Pendukung Keputusan, Bandung, PT. Remaja Karya.

Turban, E., Aronson, J., dan Ting L.P., 2005. Decision Support Systems and Intellegent Systems. New Jersey, Pearson Education.Inc.

Weron, R., 2014. Electricity price forecasting: A Review of the state -of-the-art with a look into the future, International Journal of Forecasting (30), 1030-1081. 